\title{
CALVING DYNAMICS DERIVED FROM SATELLITE SAR DATA IN SUPPORT OF MASS BALANCE ESTIMATIONS IN LANGE GLACIER, ANTARCTICA
}

\author{
Erling Johnson ${ }^{1,2}$, Dana Floricioiu ${ }^{1}$, Ellen Schwalbe ${ }^{3}$, Robert Koschitzki ${ }^{3}$, Hans-Gerd Maas $^{3}$, \\ Carlos Cardenas ${ }^{2}$, Gino Casassa ${ }^{2}$ \\ 1. German Aerospace Center (DLR), Remote sensing Institute (IMF), Oberpfaffenhofen, Germany \\ 2. Universidad de Magallanes, Punta Arenas, Chile \\ 3. Institute of Photogrammetry and Remote Sensing, Technische Universität Dresden, Germany \\ Email erling.johnson@umag.cl
}

\begin{abstract}
We present calving flux, calving rate, frontal retreat and volume change rate results in Lange Glacier from 2015 to 2017, including also velocity calculations in 2015, 2017 and 2018. The peak velocities at glacier front were between 1.0 and $1.5\left[\mathrm{md}^{-1}\right]$ near the center line with a maximum frontal retreat of $100[\mathrm{~m}]$. The glacier presents almost no volume change rate during the period analyzed and the average ice discharge is $0.026\left[\mathrm{~km}^{3} \mathrm{yr}^{-1}\right]$.
\end{abstract}

Index Terms - Glacier, Calving flux, Calving rate, Ice velocity

\section{INTRODUCTION}

Recent global low-resolution mass estimates from glaciers and ice caps show a significant deficit for many ice-covered regions over the world [1]. The uncertainty on the mass balance is still very high, in particular for calving glaciers, which are the main contributors to ice loss in certain climatic sensitive areas. At the present work a reliable method to calculate calving though remote sensing-based parameters is introduced, aiming to observe the evolution of calving glaciers and improve the understanding of the related glaciological processes.

Our test site is Lange Glacier located in the King George island the biggest of the South Shetland Islands with an extension of $1150 \mathrm{~km}^{2}$ and $150 \mathrm{~km}$ north of the Antarctic Peninsula $\left(62^{\circ} 02^{\prime} \mathrm{S} 58^{\circ} 21^{\prime} \mathrm{W}\right)$ (Figure 1). The island is almost fully covered $(90 \%)$ by an ice cap conformed by several icefields (Artowski, Krakow, Warzawa) [2]. Lange glacier belongs to Artowski icefield and flows in south east direction calving into the Admiralty Bay. According to several studies, the area the island is under a sustained increase in temperature [3] and glacier retreat [4][5].

The main purpose of this work is to provide an overview of results on glacier dynamics and set the ground for deeper analysis in complement with surface processes and in situ measurements.

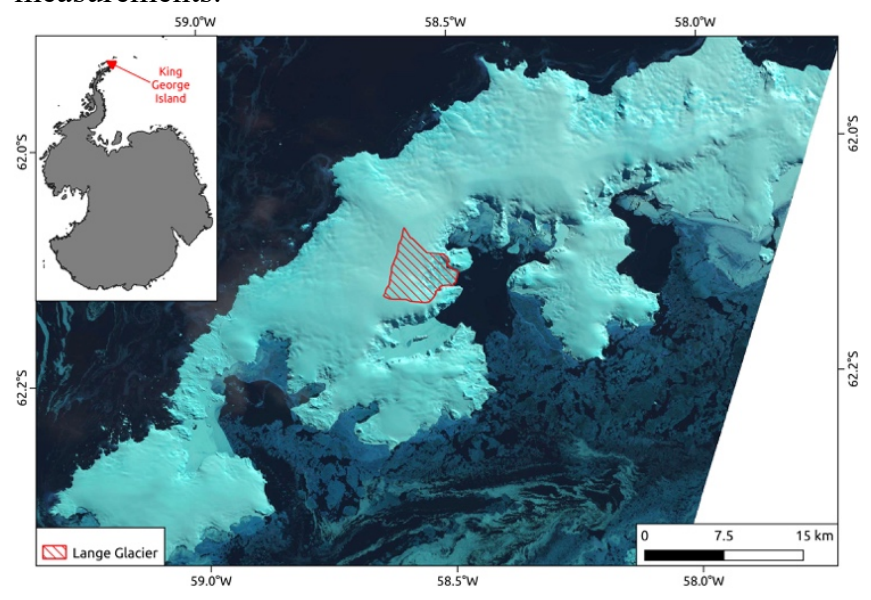

Figure 1. Lange glacier footprint (from World Glacier Inventory) and King George island location in Antarctica, superimposed over a Landsat 8 image from 2014.

\section{METHODOLOGY}

\subsection{Mass Balance}

The total mass balance of a glacier $\left(B_{n}\right)$ is the sum of all processes that add mass as accumulation $\left(B_{a}\right)$ to a glacier and remove mass from it as ablation $\left(B_{b}\right)$ and calving $\left(B_{c}\right)$, a diagram describing the configuration is presented in the Figure. The equation that takes into account all these terms are[6]: 


$$
B_{n}=B_{a}+B_{b}+B_{c}
$$

There are several techniques used to obtain the net mass balance in a certain period, the technique used in the present work is called geodetic mass balance, performed by in situ GPS measurements or through satellite images.

\subsection{Geodetic mass balance}

The geodetic mass balance is a method where the surface elevation of a glacier is determined at time periods of years [7]. The co-registration and subtraction of digital elevation models gives the elevation change in a period of time above the glacier, a further integration over the surface are needed to complete the volume change rate (VCR):

$$
V C R=\int_{A} \Delta h d A
$$

\subsection{Calving flux and calving rate}

The calving flux $\left(Q_{c}\right)$ represents the volume of ice that a glacier is losing on the terminus in a determined period of time and is directly related to the mass losses due to calving by the ice density. Considering a continuous flow were $S$ is the vertical frontal area of the glacier and $u_{c}$ is the calving rate [8]:

$$
Q_{c}=S \cdot u_{c}
$$

The calving rate calculated as the difference between the ice velocity at the terminus $\left(u_{T}\right)$ and the rate of change of the terminus position [9]:

$$
u_{c}=u_{T}-d l / d t
$$

The front position of the glacier terminus can be delineated at different dates from time series of SAR amplitude data. This is further needed for the frontal width determination (needed for $\mathrm{S}$ ) as well as for $d l / d t$. The ice surface velocity $v_{T}$ is obtained by means of amplitude correlation applied to TerraSAR-X repeat pass acquisitions. The critical part of the calving flux estimation is the ice thickness at the glacier front needed to obtain S. Here two approaches are considered. When ground penetrating radar (GPR) data from the glacierbed are available, is possible to calculate the ice thickness by combining the GPR data with glacier surface elevation from a DEM (e.g. obtained from TanDEM-X bistatic data). On the other hand, when bathymetry of the pro-glacial lake or fjord was measured it can be used together with the frontal height derived from TanDEM-X to calculate ice thickness. Normally, these sources are older or not coincident with the dates of SAR acquisitions and thus with the current frontal position of the glacier. Therefore, the bathymetry data must be adapted to the actual glacier terminus through interpolation.

\section{DATA}

The data used for this work was selected to match as close as possible the amplitude products to the interferometric products. The calving fluxes were calculated with TerraSAR$\mathrm{X}$ and TanDEM-X acquisitions close to 2015-2017. In addition, we monitored the velocity until 2018 for future comparison with in-situ measurements. A summary of the products used is presented in the Table 1.

Table 1 - Dates of TerraSAR-X, TanDEM-X and bathymetry

\begin{tabular}{lccc}
\multicolumn{4}{c}{ data. } \\
\hline Glacier & $\begin{array}{c}\text { TerraSAR-X } \\
\text { pairs }\end{array}$ & TanDEM-X & Bathymetry \\
\hline \multirow{2}{*}{ Lange } & $2015.11 .10-11.21$ & 2015.11 .27 & 2018.12 \\
& $2017.12 .08-12.19$ & 2017.07 .19 & \\
\hline
\end{tabular}

\section{RESULTS}

The velocities from Lange Glacier remains with a minor variation during the entire analysis, the frontal retreat is almost not existent in the north side of the glacier with a small increment in the south part. The Figure 2 permits to verify how the velocity changes with the distance to the front.

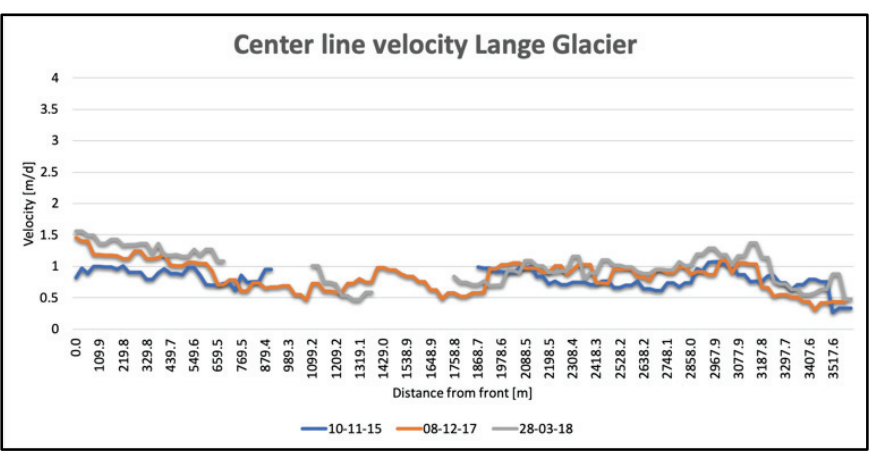

Figure 2. Center line velocities from Lange Glacier in the investigated dates.

The elevation difference in between 2015 and 2017 reflect very small changes in the plateau area that tend to increase at the front (Figure 3). Also, there are some phase unwrapping errors due to the abrupt elevation changes that are present in the southern side of the Island, this area directly after the 
upper zone of Lange Glacier is masked for changes up to \pm $15 \mathrm{~m}$.

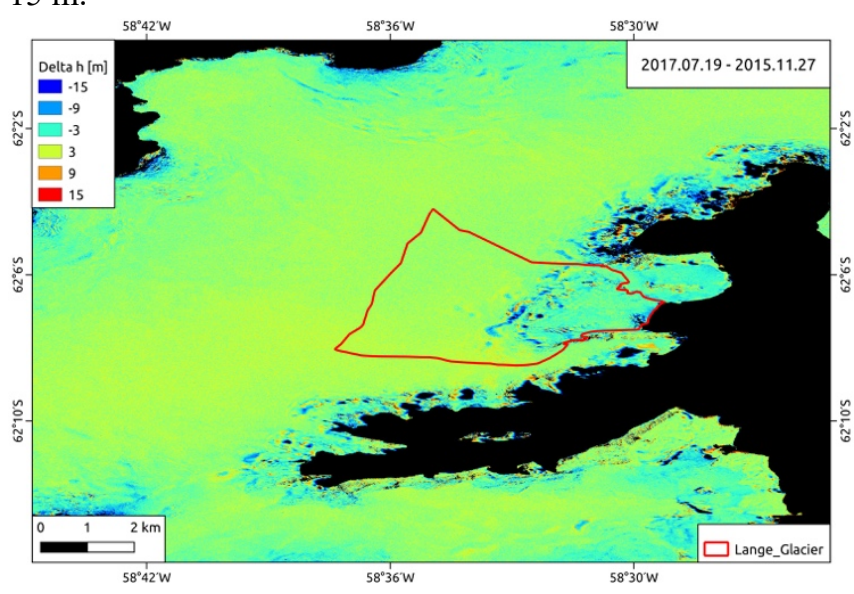

Figure 3. Elevation difference from King George island from TanDEM-X to TanDEM-X comparison.

By evaluating the equation 3 using the TerraSAR-X data pairs listed in Table 1 we obtained calving rates for the investigated epoch (Table 2). Is possible to notice a small averaged retreat through all the front and therefore a similarity between calving rate and terminus velocity.

Table 2 - Calving rates, terminus velocities and front retreat (as average for the entire front)

\begin{tabular}{lcccc}
\multicolumn{5}{c}{ retreat (as average for the entire front) } \\
\hline Glacier & Epoch & $\begin{array}{c}u_{c} \\
{\left[\mathrm{~m} \mathrm{~d}^{1}\right]}\end{array}$ & $\begin{array}{c}u_{T} \\
{\left[\mathrm{~m} \mathrm{~d}^{1}\right]}\end{array}$ & $\begin{array}{c}\text { Retreat } \\
{[\mathrm{m}]}\end{array}$ \\
\hline $\begin{array}{l}\text { Lange } \\
\text { Glacier }\end{array}$ & $2015-2017$ & 0.808 & 0.797 & -10.25 \\
\hline
\end{tabular}

Finally, the calving flux and volume change rate are calculated according to equations 3 and 2 respectively (Table $3)$. The geodetic VCR is nearly zero, this indicates a tendency to stability only impacted by retreat at front (calving flux is higher that VCR) and a dynamic area of high slope.

Table 3 - Calving flux and volume change rate (VCR)

\begin{tabular}{lccc}
\hline Glacier & Epoch & $\begin{array}{c}\text { Calving flux } \\
{\left[\mathrm{km}^{3} \mathrm{yr}^{-1}\right]}\end{array}$ & $\begin{array}{c}\text { Geodetic } \\
\text { VCR } \\
{\left[\mathrm{km}^{3} \mathrm{yr}^{-1}\right]}\end{array}$ \\
\hline $\begin{array}{l}\text { Lange } \\
\text { Glacier }\end{array}$ & $2015-2017$ & 0.026 & -0.009 \\
\hline
\end{tabular}

\section{DISCUSSION \& CONCLUSIONS}

The calving rate determination allows a detailed analysis at the glacier front and also the possibility to follow the evolution of the terminus retreat in time. The results obtained by SAR satellite are comparable to in-situ measurements in 2018 from [10].
Obtaining the calving flux allows in a future work to verify the relationship between the total mass balance and the amount of ice discharged, as well as the indirect calculation of the surface mass balance, representing a direct link to the climatic and energetic models.

\section{ACKNOWLEDGEMENTS}

- The SAR data were provided within the data proposals OCE1681.

- The Bathymetry data was provided by Diego Fernandez Mojica-Moncada.

- This work is intended as a part of the INACH project CAMB-KGI (RT_50-16).

- The main author doctoral work is supported by Becas Chile (CONICYT) and the German Academic Exchange Service (DAAD).

\section{REFERENCES}

[1] S. Solomon et al., "IPCC fourth assessment report (AR4)," Clim. Change, 2007.

[2] M. Rückamp, M. Braun, S. Suckro, and N. Blindow, "Observed glacial changes on the King George Island ice cap, Antarctica, in the last decade," Glob. Planet. Change, vol. 79, no. 1-2, pp. 99-109, Oct. 2011.

[3] M. Braun, H. Saurer, and H. GOßMANN, "Climate, energy fluxes and ablation rates on the ice cap of King George Island," p. 17, 2004.

[4] J. C. Simões, U. F. Bremer, F. E. Aquino, and F. A. Ferron, "Morphology and variations of glacial drainage basins in the King George Island ice field, Antarctica," Ann. Glaciol., vol. 29, pp. 220-224, 1999.

[5] B.-K. Park, S.-K. Chang, H. I. Yoon, and H. Chung, "Recent retreat of ice cliffs, King George Island, South Shetland Islands, Antarctic Peninsula," Ann. Glaciol., vol. 27, pp. 633-635, 1998.

[6] H. Rott, M. Stuefer, A. Siegel, P. Skvarca, and A. Eckstaller, "Mass fluxes and dynamics of Moreno Glacier, Southern Patagonia Icefield," Geophys. Res. Lett., vol. 25, no. 9, p. 1407, 1998.

[7] N. Haakensen, "Glacier mapping to confirm results from mass-balance measurements," Ann. Glaciol., vol. 8, pp. 73-77, 1986.

[8] M. F. Meier, L. A. Rasmussen, A. Post, C. S. Brown, and W. G. Sikonia, "Predicted timing of the disintegration of the lower reach of Columbia glacier, Alaska," 1980.

[9] D. I. Benn, C. R. Warren, and R. H. Mottram, "Calving processes and the dynamics of calving glaciers," Earth-Sci. Rev., vol. 82, no. 3-4, pp. 143-179, 2007.

[10] E. Schwalbe, R. Koschitzki, B. Schröter, C. Cardenas, G. Casassa, E. Johnson and H.-G. Maas, "StereoPhotogrammetric measurement of spatio-temporal velocity fields at Lange Glacier, King George Island” LAGIRS, Santiago, Chile, 2019. 